\title{
Ethno-Aesthetic Communication in the Context of the Formation of Technological Culture of Students in the System of Continuing Education
}

\section{La comunicación etnoestética en el contexto de la formación de la cultura tecnológica de los estudiantes en el sistema de educación continua}

\begin{abstract}
Alsou I. Galeeva
Kazan, The Republic of Tatarstan, Russia, Kazan Federal University. Institute of International Relations, Department of Foreign Languages in the Field of International Relations.
\end{abstract}

ORCID: https://orcid.org/0000-0002-6083-5910

\section{Anastasia Fakhrutdinova}

Kazan, The Republic of Tatarstan, Russia, Kazan Federal University. Institute of International Relations

ORCID: https://orcid.org/0000-0001-7872-7507

\section{Gennady Nikitin}

Cheboksary, (Volga district, Chuvash region)

Chuvash state pedagogical University named after I. Yakovlev, Cheboksary 428000, Russia, Chuvash Republic, Cheboksary, K. Marx, 38.

ORCID: https://orcid.org/0000-0003-4078-5044

\section{Mikhail Grigoryevich Kharitonov}

Cheboksary (Volga district, Chuvash region)

Chuvash state pedagogical University named after I. Yakovlev, Cheboksary 428000, Russia,

Chuvash Republic, Cheboksary, K. Marx, 38.

ORCID: https://orcid.org/0000-0002-2115-1591

Received 09-08-20 Revised 10-10-20

* Correspondence

Email: AlsIGaleeva@kpfu.ru
Citation:

Alsou I. Galeeva, Anastasia Fakhrutdinova, Gennady Nikitin Cheboksary, Mikhail Grigoryevich Kharitonov. (2021). EthnoAesthetic Communication in the Context of the Formation of Technological Culture of Students in the System of Continuing Education. Propósitos y Representaciones, 9(SPE2), e1008. doi http://dx.doi.org/10.20511/pyr2021.v9nSPE2.1008 


\section{Summary}

The relevance of the problem presented in this study is conditioned by the fact that the multifactorial nature of qualities of technological culture of the individual requires a search for paradigms, an identification of the range of approaches aimed at developing not only technological, professional, but also cultural competences of students in multiparadigmatic viewpoint. The purpose of the article is to theoretically substantiate the polyparadigmatic approach to the formation of technological culture of students in the system of continuing education based on ethno-aesthetic values. The leading method for the research of this problem is the method of concretization, which allows us to consider the formation of motivational, cognitive, activity (practical) - technologically important personal qualities (Belentsov S. I, Fahrutdinova A. V, 2017). The structure of the polyparadigmatic approach to the formation of technological culture of students in the system of continuing education based on ethno-aesthetic values includes axiological, cultural, socio-cultural, activity-technological, ethnopedagogical, and ethno-aesthetic approaches. The polyparadigmatic approach has an integrative basis, it is based on scientific and ethnic knowledge expressed in the form of concepts, didactics of technological and higher education, ethno-aesthetic didactics, which ensure the continuity of the formation of the components of technological culture of students in the system 'school - University - additional education'.

Keywords: ethno-aesthetic communication, polyparadigmatic approach, formation of technological culture, spirituality, ethno-aesthetic didactics

\section{Resumen}

La relevancia del problema que se presenta en este estudio está condicionada por el hecho de que el carácter multifactorial de las cualidades de la cultura tecnológica del individuo exige una búsqueda de paradigmas, una identificación del abanico de enfoques orientados a desarrollar no solo tecnológicos, profesionales, sino también Competencias culturales de los estudiantes en el punto de vista multiparadigmático. El propósito del artículo es fundamentar teóricamente el enfoque poliparadigmático de la formación de la cultura tecnológica de los estudiantes en el sistema de educación continua basado en valores etnoestéticos. El método principal para la investigación de este problema es el método de concretización, que nos permite considerar la formación de cualidades personales motivacionales, cognitivas, (prácticas) - tecnológicamente importantes (Belentsov S. I, Fahrutdinova A. V, 2017). La estructura del enfoque poliparadigmático para la formación de la cultura tecnológica de los estudiantes en el sistema de educación continua basado en valores etnoestéticos incluye enfoques axiológicos, culturales, socioculturales, de actividad tecnológica, etnopedagógicos y etnoestéticos. El enfoque poliparadigmático tiene una base integradora, se fundamenta en conocimientos científicos y étnicos expresados en forma de conceptos, didáctica de la educación tecnológica y superior, didáctica etnoestética, que aseguran la continuidad de la formación de los componentes de la cultura tecnológica de los estudiantes. en el sistema 'escuela - Universidad - educación adicional'.

Palabras clave: comunicación etno-estética, abordaje poliparadigmático, formación de cultura tecnológica, espiritualidad, didáctica etno-estética

\section{Introduction}

Socio-economic transformations in society that led to changes in traditional values have had a mixed impact on the development of a negative attitude to activity among some young people. At the same time, pedagogical ideas, approaches, and paradigms aimed at technological education are not able to fully ensure the qualitative level of technological culture of the students' personality (Serebrennikov, 2017). The problem requires solving worldview problems which can not do without introducing students to activitities as the basis of culture (Kreber, Kluckhohn, 1952), technology (Salomon, Whatis, 1984). The multiplicity of development of technologically 
important personal qualities of students makes it necessary to integrate scientific and ethnic knowledge in the form of 'humanized' content, mentality (Bull, Fruehling, Chatlrgy, 1992), (Krayevsky and Khutorskoy, 2007). The transformation of ideals that represent the scientific paradigm (Arsaliev, 2013), the ideals that have been tested for centuries, and the norms of traditional pedagogical measures that have motivated young people to active life, actualize the importance of substantiating the essence and structure of the polyparadigmatic approach to the formation of technological culture of students in the system of continuing education based on ethno-aesthetic values.

\section{Methodological Framework}

\section{Tasks of the study}

The polyparadigmatic approach to substantiating the approaches to the formation of technological culture of students in the system of continuing education based on ethno-aesthetic values was aimed at solving the following tasks:

1) substantiation of the nature and structure of the polyparadigmatic approach to the problem of research;

2) definition of the concept of polyparadigmatic approach;

3) ethno-aesthetic characteristics of the content of scientific approaches;

4) highlighting the conceptual aspects of the implementation of the designated process.

\section{Research methods}

The research tasks were solved using the following methods: 1) theoretical - analysis of literature, normative documents, generalization of pedagogical experience, synthesis, etc.

2) empirical - study, generalization of research, archival, field materials, samples of material and spiritual culture; conversation, pedagogical observation of students to identify their attitude to the problem of research.

\section{Base of research}

The research base was Municipal budget educational institution 'Secondary school No. 2' of the city of Shumerl, Municipal budget educational institution 'Secondary school No. 22', Municipal budget educational institution 'Secondary school No. 28', Municipal budget educational institution 'Secondary school No. 49', Municipal budget educational institution 'Secondary school № 62' of the city of Cheboksary, ethnopedagogical classes of the Kuges Secondary school No. 1 of Cheboksary district, Shorshelsky Secondary school named after cosmonaut A. G. Nikolaev Marposadsky, Shimkusskaya Secondary school of Urmarsky district of the Chuvash Republic, faculty of technology and economics of the 'Chuvash state pedagogical University named after I. Y. Yakovlev', 'Chuvash Republic Institute of education'.

\section{The methodological basis for the justification of the multiparadigmatic approach}

The methodological basis for the elaboration and justification of a polyparadigmatic approach to the formation of technological culture are the following approaches: systemic (Krayevsky, 2008), human-personal (Amonashvili, 1999); axiological (Slastenin, Isaev, Shiyanov, 2002); cultural (Simonenko, Retivykh, Matyash, 1999), activity (Zagvyazinsky, 2005) design approach (pitt, 1999), ethnopedagogical (Volkov, 2004), polyparadigmatic (mukhametzyanova, yalalov, 2002).

\section{Results}




\section{The nature, structure of multiparadigmatic approach}

The nature of the polyparadigmatic approach comes from the theoretical ideas of $\mathrm{T}$. Kuhn about the concept of 'paradigm' (Kuhn, Thomas, (1962), ethical and aesthetic paradigm (Guattari, 1995). The conceptual idea aimed at the synthesis of scientific knowledge and ethnic values is considered in methodological, ethnopedagogical, and ethno-aesthetic patterns and expresses the essence of a set of approaches to the formation of personality in activity. The ethno-aesthetic aspect of solving the worldview problem in the process of forming technological culture is focused on giving the essence, structure of the polyparadigmatic approach a spiritual orientation.

Hence, the multiparadigmatic approach to forming technological culture of students is a methodological reference point of the set of rules of technological education and ethno-aesthetic values aimed at defining the objectives, search for mechanisms and instruments, indicators and technologies, able to carry out integrative processes of development of 'picture of the world', understanding of the technosphere as the basis for socially adaptive human of technological culture of the twenty-first century.

The formation of a technological, spiritual worldview that can provide critical, creative, and project thinking is the basis of the structure of the polyparadigmatic approach, which consists of axiological, cultural, activity-technological, socio-cultural, ethnopedagogical, ethno-aesthetic, and other approaches.

\section{Content of approaches}

The metaprinciple of justification of multiparadigmatic approach is axiological approach. The essence of the approach is aimed at defining the system of pedagogical guidelines through the prism of ethno-aesthetic values. Considering them as a component of culture, the student (person) in the system of technological education is the highest value. In this system, the signs of the value orientation of the formation of technological culture that determine the humanistic basis are aesthetic feelings, love, meanings, ideals, concepts of good and evil, humanness, conscience, honor, joy, happiness, ideas. Such an aesthetic and moral feature as hard work, accompanying the approach, is represented by the national idea of forming a technological culture among students. The process is carried out through the principle of value orientation, ensuring the priority of the transformation of educational space with ethno-aesthetic values according to the laws of beauty; transformation of ethno-aesthetic values by the categories of design; appeal of students to the values of the profession, technical and pedagogical specialties.

The axiological priority of the polyparadigmatic approach is considered to be the basis for improving the system of forming technological culture with spiritual values within the framework of the cultural approach. Its essence, justified in the concept of V. V. Kraevsky, I. Y. Lerner and M. N. Skatkin as 'opposition to natural science and technical components of education' (Berezhnova and Kraevsky, 2008), E. V. Bondarevskaya - as components of culture serve a person for 'self-development and self-determination in the world of cultural values' (Bondarevskaya, 2000). Their meanings are a reference point for the inclusion of ethno-aesthetic values of social experience formed on the basis of activities consisting of technologies and aesthetic elements of life in the process under study. The process is carried out on the principle of cultural conformity, allowing the representation of culture as the basis of ethno-aesthetic values; orientation of culture in determining the purpose, task, content of technological education; ensuring the unity of material and spiritual culture; the formation of personality in a combination of universal and national aesthetic values; improving the status of humanitarian disciplines with spiritual, aesthetic and moral content; harmonizing the personality with the development of an active worldview.

The activity-technological approach is based on the position of the theory of activity, technology as a general cultural paradigm, humanization based on ethno-aesthetic values that can ensure active participation in the educational process. The essence of this approach is based on the conceptual assumption that an activity aimed at knowledge, transformation in all its forms, can not do without technology. The concept taken from the works (Salomon, J. Whatis, 1984), V. P. 
Bespalko 'Components of pedagogical technology' is used as a method of substantiating the activity-technological approach to the concept of 'technology'. It says that any work (activity) can be called technology or art. Agreeing with the author, we believe that art is a consequence of intuition, and technology is a science. The integrability of sensory and scientific categories is explained by the fact that the process begins with art, ends with technology, and begins all over again. The approach is implemented on the principle of practicality, which determines the appeal to study, work in the direction of the self: want, need, can; coverage of invariant components of human activity: labor culture, culture of working with digital technologies, project culture, information culture, environmental culture, home culture, technologization of the content and process of formation of technological culture within the aesthetics of socio-cultural values.

The socio-cultural approach considers the system of formation of technological culture of students through the prism of cultural and social values. The approach, in the context of the principle of sociality, is implemented by the tendencies of continuity, mentality, and humanity. Ethnic components as pedagogical components provide for the consideration of mentality in the relations of ethnic culture subjects in the context of aesthetic values of traditional material and spiritual culture (meanings, symbols, ideals, values, traditions, customs).

Ethno-aesthetic aspects of the principle form the basis of socialization of the content and process of formation of technological culture. Socialization is understood as the assimilation by students of a system of technological, pedagogical, spiritual knowledge in the context of pedagogical norms and ethno-aesthetic values of society, science, which contributes to adaptation in the socio-economic space, self-realization in educational and professional activities (Mefodeva M. A, Fakhrutdinova A. V, Ukhimenko A. N)

Ethnopedagogical approach to the formation of technological culture of students is a link of individual, general, special between pedagogical views in society and scientific pedagogy in social institutions 'school-University-additional education'. The approach serves as a methodological key to ethnopedagogization of the content and process of formation of technological culture in the synthesis of scientific and ethnic knowledge: ethno-aesthetic values, principles, tools, instructions in the context of ideas of humanism (the basis of education), moral principles, labor training, where work is a category, the basis of activity that characterizes the sign of spirituality, hard work - a property of aesthetic development of the individual. The ethnopedagogization in the continuous education system is determined by the principle of ethnopedagogicality, which defines the purpose; systematizes age characteristics of students for the purpose of research in the framework of pre-University, University and postgraduate education; determines the regional-ethnic aesthetic tendency of formation, socialization of the individual.

The ethno-aesthetic approach to the problem under study is a sensory form of the subject of ethnopedagogics, which has the function of motivating subjects of continuing education to a wide range of activities. Under ethno-aesthetic approach, in the framework of the research problem, is a reference point for the construction of the model of the subject of education as an integral person of technological culture, on the basis of integration of ethno-aesthetic values into scientific ideas of humanization of continuity of objectives, content of education of the individual; humanization of the process in the context of general human values. The approach serves as a direction for reformatting the surrounding social, ethno-aesthetic experience of preparing for life in accordance with the requirements of the Federal state educational standards, the development of the labor market in the context of the ethno-aesthetic principle. The principle is implemented in the categories of aesthetic relations, aesthetic education, and aesthetic activity: harmony, beauty, and simplicity in the synthesis of ethno-aesthetic values. (Mefodeva M., Khayrutdinov R., Fakhrutdinova A., 2017). The ethno-aesthetic value orientations of the above-mentioned approaches are presented as an integrative field that can synthesize scientific and ethnic knowledge.

\section{Discussions}


The theoretical aspects of the polyparadigmatic approach in methodological knowledge can be traced in the research of Sh. A. Amonashvili (1999), E. V. Berezhnova, V. V. Kraevsky (2008). The polyparadigmatical approach in the theory and practice of personality-oriented education is considered by E. V. Bondarevskaya (2000). The trend of polyparadigmality in technological education is expressed in the studies of P. R. Atutov (1997), V. D. Simonenko, M. V. Retivykh, N. V. Matyash (1999), O. A. Kozhina (2006), E. S. Glozman, E. N. Kudakova (2019). From multiparadigmatic point of view were considered the directions of labor education of L. N. Nugumanova (2011), ethno-cultural education of G. V. Mukhametzyanova, F. G. Yalalov (2002), T. Y. Shpikalova, T. I. Baklanova, L. V. Ershova (2006), formation of ethno-aesthetic, technological culture of M. I. Aldoshina (2009), G. A. Nikitin and M. G. Kharitonov (2019), the development of ethnic identity (J. Piaget, A. M. Weil, 1951). Given the breadth of research on the polyparadigmatic approach in methodological knowledge, there are very few researches aimed at forming a technological culture in the context of ethno-aesthetic values.

\section{Conclusion}

It is established that the theoretically founded polyparadigmatic approach, including axiological, cultural, socio-cultural, activity-technological, ethnopedagogical, ethno-aesthetic approaches, principles are aimed at the constant development of not only technological, general professional, but also general cultural competencies in a spiritual context. The strategic line of implementation of the polyparadigmatic approach in the system 'school - University -additional education' is the integration of scientific and ethnic knowledge, expressed in the form of didactics of technological and higher education, ethno-aesthetic didactics. Ethno-aesthetic didactics serves as a socializing tool for approaches to solving worldview issues within the framework of motivating students to work, encouraging the continuous development of cognitive, activity (practical) and technologically important personal qualities that can put their soul into the work (activity).

The materials of the article will be useful in practical terms for teachers of technology, teachers of additional education, University teachers, educators in selecting and structuring the content of the formation of technological culture of students in the system of continuing education based on ethno-aesthetic values.

The obtained results of this research are not final, but allow us to identify a number of scientific problems and promising areas that require further study: the deepening and expansion of the tools of ethno-aesthetic didactics; the development of scientific and methodological support for remote self-formation of components of technological culture.

\section{Acknowledgements}

\section{The work is performed according to the Russian Government Program of Competitive Growth of Kazan Federal University.}

\section{References}

Amonashvili, Sh. A. (1999). A human-personal approach to children. Moscow: Institute of practical psychology; Voronezh: 'MODEK research and production association'.

Arsaliev, Sh. M-H. (2013). The methodology of modern pedagogy. Moscow: Helios ARV-49.

Belentsov, S. I., Fahrutdinova, A.V., \& Okulich-Kazarin, V. (2017). Education of civic consciousness in George Kershenshteyner's creativity. European Journal of Contemporary Education, 6(1), 5-13.

Berezhnova, E.V., \& Kraevsky V.V. (2008). Methodology of pedagogy. Moscow: Academy - 118.

Bondarevskaya, E. V. (2000). Theory and practice of personality-oriented education. Rostov n/D: Rostov state pedagogical University. -44.

Bull, B.L., Fruehling, R.I., \& Chatlrgy, V. (1992). The Ethnics of multicultural and bilingual education - New York. - 209 p.

Croce, B. (1941). Il carattere de la filosofia moderna. Bari. 
Guattari, F. (1995). Chaosmosis an ethico-aesthetic paradigm. Bines, J Pefanis. - Sydney: Power University of Fine Arts, -135 p.

Krajevsky, V.V., \& Khutorskoy, A.V. (2007). The basics of learning. Didactics and methods. Moscow: Academy. -153.

Kreber, A. L., \& Kluckhohn, C. (1952) Culture: a Critical Review of Concepts and Definitions. Paperspeaboy Mus, 1, 47-181.

Kuhn, T.S. (1962). The Structure of Scientific Revolutions. Chicago, IL: University of Chicago Press.

Mefodeva, M., Khayrutdinov, R., \& Fakhrutdinova, A. (2017). Value education philosophy in Russia and India. $9^{\text {th }}$ international conference on education and new learning technologies, 9886-9891.

Mefodeva, M.A., Fakhrutdinova, A.V., \& Ukhimenko, A.N. (2017). Historical perspectives of spiritual and moral education in India. Man in India, 97(8), 71-77.

Mukhametzyanova, G. V., \& Yalalov, F. G. (2002). Multiparadigmatic approach to the modeling of national secondary education. Nizhnekamsk: Chishme.

Nikitin, G.A. \& Kharitonov, M.G. (2019). Pedagogical bases of formation of technological culture. Bulletin of the Chuvash state pedagogical University named after I. Y. Yakovlev, 2(102), 153-157. DOI 10/26293/ chgpu. 2019.102.2.021

Nikitin, G.A. (2017). Ethno-esthetics. Cheboksary: Chuvash state pedagogical University.

Nugumanova, L.N. (2011). Profile-oriented labor education of students in a modern comprehensive school (Dissertation ... of doctor of pedagogical sciences). - Cheboksary.

Piaget, J., \& Weil, A.M. (1951). The development in children of the idea of the homeland and of relations with other countries. International Social Science Bulletin, 3, 561-578

Pitt, J. (1999). Design in technology education - the UK experience. Thesis report of international conference. Saint Petersburg: Smolny University press, 286 p.

Salomon, W.J. (1984). Technology. The issue of its origins and definitions. History of technology, $1,113-156$.

Serebrennikov, L.N. (2017). Technology training methods. - Moscow: Uwrite. 70-82.

Shpikalova, T.Ya., Baklanova, T.I., \& Yershova, L.V. (2006). Concept of ethno-cultural education in the Russian Federation. Shuya: News. -23.

Simonenko, V.D., Retivykh, M.V., \& Matyash, N.V. (1999). Technological education of schoolchildren. Theoretical and methodological aspects. Bryansk: BSPU, 60-63.

Slastenin, V.A., Isaev, I.F., \& Shiyanov, E.N. (2002). Pedagogy. Moscow: School Press. 113.

Volkov, G.N. (2004). Chuvash ethnopedagogics. Cheboksary: JSC 'Cheboksary printing house, 1, 459-477.

Zagvyazinsky, V.I. (2005). Methodology and methods of psychological and pedagogical research. Moscow: Academy. 